\title{
Pendampingan Pemanfaatan Teknologi Digital Untuk Meningkatkan Pemasaran Toko Roti di Pabian Sumenep
}

\author{
Taufik rahman*1, Yudha Nurdian² \\ 1,2Prodi Sistem Informasi, Fakultas Ilmu Komputer, Universitas Jember \\ *e-mail : rtaufik9930@gmail.com¹, yudhanurdian78@gmail.com²
}

\begin{abstract}
The existence of a covid-19 virus pandemic in Indonesia since March 2020, then it has felt its impact on the economic sector throughout Indonesia, no exception in the village Pabian Sumenep Regency. People are affected such as losing jobs, public purchasing power is reduced. Similarly, the income of some communities in the village of Pabian which is partially livelihood as a merchant. The results of trading become lonely customers because of the social policy distancing that makes the community restrict themselves to leave the house. This situation made the community economy in Pabian village disturbed. For example, in one of the community who has a home bread business Warung Soeka. Through the program KKN UNEJ back to village, it is expected to be able to help people survive during this pandemic and for a period that is sustainable through the utilization of digital technology. This can be done innovate in the development of various bread making, good packaging, and effective sales by utilizing digital marketing on the E-commerce as well as social media as a means of sales strategy.
\end{abstract}

Keywords: covid-19, bread, entrepreneur, digital marketing

\begin{abstract}
Abstrak
Adanya pandemi virus covid-19 di Indonesia sejak bulan maret 2020 lalu sangat terasa dampaknya pada sektor perekonomian di Indonesia, tak terkecuali pada desa Pabian Kabupaten Sumenep. Masyarakat terkena dampak seperti kehilangan pekerjaan, daya beli masyarakat pun berkurang. Begitu juga dengan pendapatan sebagian masyarakat di desa Pabian yang sebagian bermata pencaharian sebagai pedagang. Alhasil dagangan menjadi sepi pelanggan karena adanya kebijakan sosial distancing yang membuat masyarakat membatasi diri untuk keluar rumah. Keadaan tersebut membuat perekonomian masyarakat di desa Pabian terganggu. Contohnya pada salah seorang masyarakat yang memiliki usaha roti rumahan Warung Soeka. Melalui program KKN UNEJ back to village ini, diharapkan mampu membantu masyarakat bertahan dalam masa pandemi ini maupun untuk periode yang berkelanjutan melalui pemanfaatan teknologi digital. Hal ini bisa dilakukan dengan mengembangkan inovasi pembuatan roti yang bervariasi, pengemasan yang baik, serta penjualan yang efektif dengan memanfaatkan digital marketing pada E-commerce maupun media sosial sebagai sarana strategi penjualan.
\end{abstract}

Kata Kunci : covid-19, roti, wirausaha, pemasaran digital

\section{PENDAHULUAN}

Perkembangan Teknologi Informasi dari waktu ke waktu semakin canggih, banyak inovasi- inovasi baru bermunculan demi mendukung kebutuhan manusia. Pada dasarnya teknologi bertujuan untuk memberikan kemudahan dari berbagai aspek kehidupan, baik dalam bekerja, berkomunikasi bahkan menyelesaikan permasalahn yang ada di masyarakat (Garaika, 2020). Namun terkadang teknologi juga dapat memberikan dampak negatif terhadap kehidupan sosial di masyarakat. Perkembangan teknologi dan aplikasi yang ada saat ini bahkan telah mempengaruhi perilaku sosial seseorang seperti dalam memesan makanan melalu aplikasi seperti gofood, grabfood, dan bahkan berbelanja melalui berbagai platform E-Commerce.

Electronic commerce atau E-commerce adalah suatu proses berbisnis dengan menggunakan teknologi elektronik yang menghubungkan antara perusahaan, konsumen, dan masyarakat dalam bentuk transaksi elektonik. Dengan demikian pada prinsipnya bisnis dengan E-commerce adalah bisnis tanpa warkat paperless trading (Munir Fuady, 2002). Kegiatan bisnis dalam E- commerce terdiri dari konsumen (consumers), manufaktur (manufactures), service providers dan pedagang perantara (intermediateries) dengan menggunakan jaringan-jaringan komputer (computer network) yaitu internet (Renny Sari Dewi, 2019) (Siska Candra Ningsih, 
2020) (Martinus Maslim, 2020) (Ananta Kusuma Yoga Pratama, 2020). Perkembangan internet yang pesat juga menjadi faktor pendorong berkembangnya E-Commerce serta meningkatnya pengguna social media. Seiring dengan perkembangan E-Commerce, Media Sosial menjadi sarana komunikasi bagi pelaku usaha dan konsumen. Bahkan dalam pemanfaatannya media sosial juga dijadikan sebagai sarana promosi bagi para pelaku usaha. Sebagaimana diketahui bahwa perkembangan teknologi informasi telah membuka jalan bagi peluang-peluang baru dalam bisnis, melalui E-commerce. E-commerce tidak saja memperluas arus barang dan jasa, namun juga menciptakan kesempatan bagi individu untuk terlibat sebagai pelaku usaha.

Adanya pandemi virus covid-19 di Indonesia sejak bulan maret 2020 lalu sangat terasa dampaknya pada sektor perekonomian di seluruh penjuru Indonesia, tak terkecuali pada desa Pabian, Kabupaten Sumenep. Masyarakat terkena dampak seperti kehilangan pekerjaan, serta daya beli yang berkurang. Begitu juga dengan pendapatan sebagian masyarakat di desa Pabian yang bermata pencaharian sebagai pedagang. Alhasil dagangan menjadi sepi pelanggan karena adanya pembatasan yang membuat masyarakat membatasi diri untuk keluar rumah. Keadaan tersebut membuat perekonomian masyarakat di desa Pabian terganggu.

Berdasarkan permasalahan diatas, dalam kegiatan KKN UNEJ Back to Village penulis ingin memberdayakan wirausaha produk home industry khususnya produk kue kering dan roti warung soeka di desa Pabian, Kabupaten Sumenep. Dalam upaya memberdayakan wirausahawan tersebut maka perlu membuat pemahaman mengenai bagaimana berinovasi dalam pembuatan produk hingga memasarkannya melalui perkembangan teknologi saat ini. Hal ini bertujuan agar wirausahawan home industry tersebut dapat memahami dan mengimplementasikan pemanfaatan teknologi dalam pengembangan serta pemasaran produk melalui pelatihan-pelatihan yang diadakan selama kegiatan.

\section{METODE}

Metode dalam pelaksanaan KKN UNEJ Back to Village ini dilakukan dengan mengadakan pelatihan, pendampingan, serta memasarkan langsung produk di E-commerce maupun di media sosial. Metode tersebut terprogram dan dilakukan bertahap setiap minggu selama 45 hari.

\section{A. Perencanaan}

Tahap awal Kegiatan KKN ini adalah dengan menentukan rencana program selama 45 hari di masa pandemi Covid-19. Pada tahap ini penulis melakukan survei untuk mengetahui permasalahan mitra sehingga dapat dicari solusinya. Survei ini dilakukan dengan melakukan wawancara kepada mitra KKN maupun perangkat desa terkait untuk mendukung program KKN UNEJ Back to Village.

\section{B. Pelaksanaan}

Tahap pelaksanaan ini merupakan tahap dilaksanakannya program kegiatan yang telah di rencanakan sebelumnya. Program kegiatannya berupa pelatihan serta pendampingan praktek langsung agar peserta memahami materi pelatihan yang telah disampaikan sebelumnya. Materi disiapkan terlebih dahulu dengan memperhatikan kesesuaian informasi. Pemateri selama pelatihan ini dapat berasal dari luar instansi Unej maupun mahasiswa KKN sendiri. Pelatihan ini terdiri dari pelatihan inovasi pengembangan dan pengemasan produk, pelatihan pemasaran melalui E-commerce, pelatihan pembuatan label produk menggunakan Canva dan pelatihan Strategi Social Media Marketing.

C. Evaluasi

Tahap evaluasi dilakukan di minggu terakhir KKN terhadap kegiatan program KKN selama 45 hari. Evaluasi dilakukan dengan melihat hasil penjualan, dampak adanya program KKN UNEJ Back to Village terhadap mitra serta kendala selama program yang telah dijalankan. 

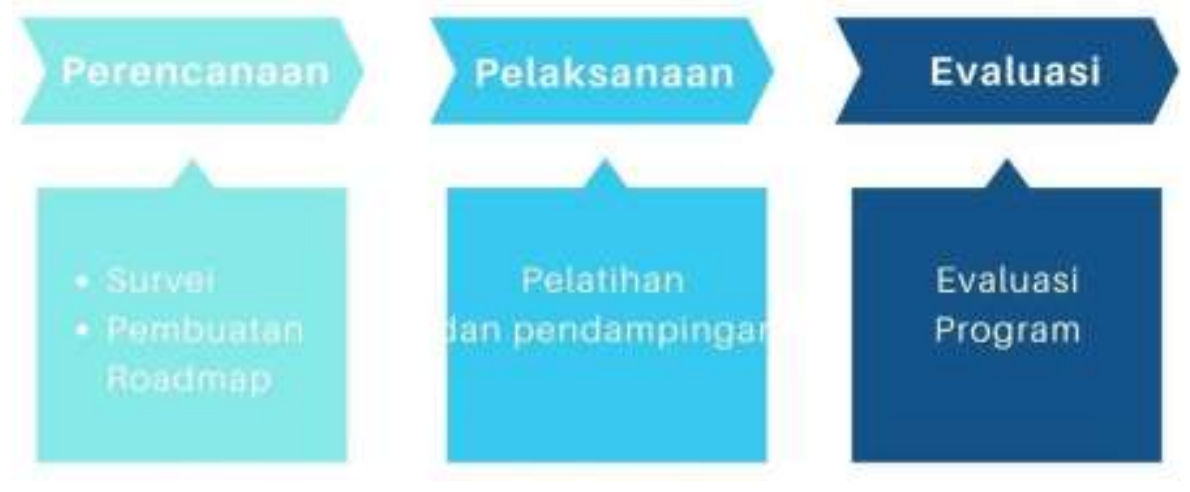

Gambar 1. Alur Kegiatan KKN

\section{HASIL DAN PEMBAHASAN}

Pelaksanaan KKN UNEJ Back To Village selama 45 hari dilaksanakan dari tanggal 1 Juli hingga 14 Agustus 2020. Selama 45 hari banyak kegiatan yang telah dilaksanakan seperti pelatihan serta praktek langsung bersama mitra KKN. Kegiatan KKN di masa pandemi Covid-19 ini dilakukan dengan tetap memperhatikan protokol Kesehatan yang ketat. Pada minggu pertama dilakukan diskusi bersama mitra KKN untuk menggali permasalahan dan mencari solusinya.

Setelah Mengetahui permasalahan mitra, dilanjutkan dengan program pelatihan-pelatihan yang dimulai di minggu kedua. Pelatihan pertama yang diberikan kepada mitra adalah mengenai inovasi pengembangan dan pengemasan produk. Kegiatan ini mengajak pengusaha lokal ibu Arinda Hariyadi sebagai mentor untuk memberikan materi kepada mitra KKN. Materi ini memberikan pemahaman kepada peserta untuk lebih berinovasi serta memberikan pengetahuan dalam membuat pengemasan yang menarik sehingga dapat menarik pelanggan. Setelah memberikan materi, peserta diminta langsung mencoba mempraktekkan dalam membuat desain kemasan yang lebih menarik didampingi dengan mentor.

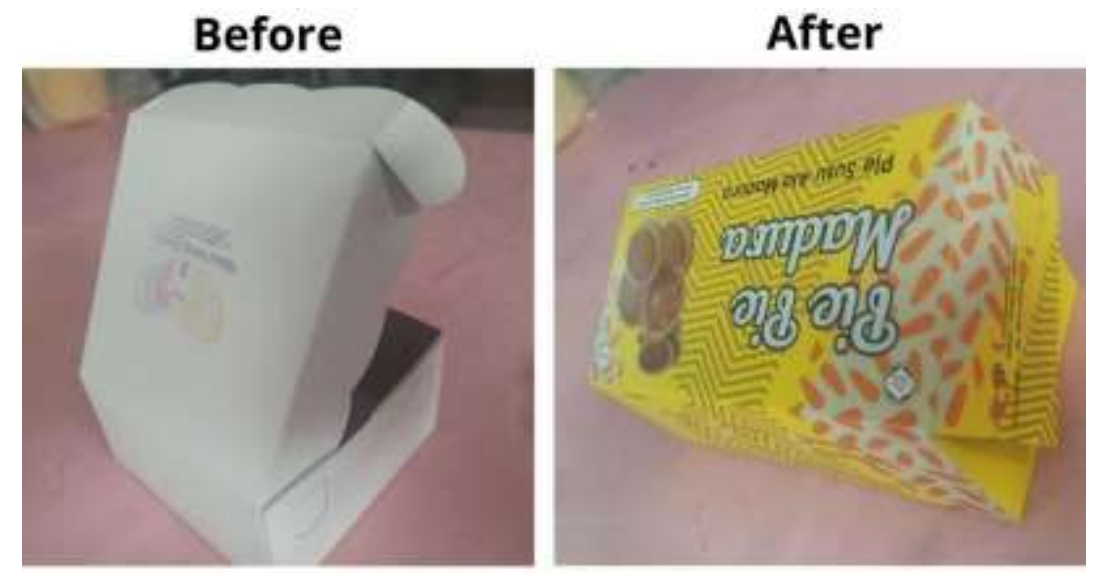

Gambar 2. Kemasan Sebelum dan Sesudah Pelatihan

Pelatihan berikutnya yaitu Pelatihan Pengenalan Platform E-commerce yang diadakan di minggu selanjutnya. Dalam pelatihan ini, penulis sebagai mentor memperkenalkan peserta pada berbagai macam platform E-commerce beserta cara menggunakannya. Mentor juga mendampingi peserta dalam membuat toko di salah satu platform E-commerce yaitu Shopee. Dengan adanya pelatihan ini diharapkan produk yang sebelumnya dijual hanya secara konvensional oleh mitra di tokonya sendiri dapat dipasarkan melalui E-commerce tersebut. 


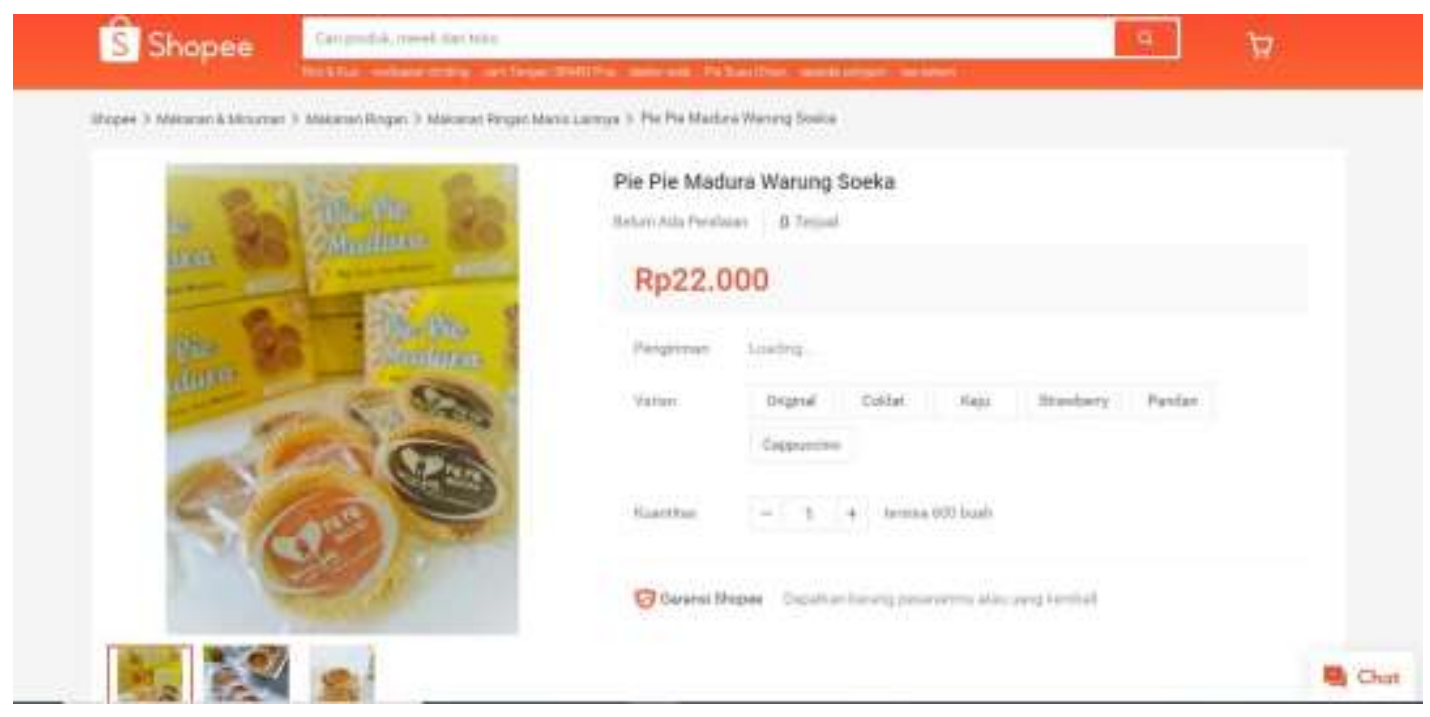

Gambar 3. Pemasaran Produk di Shopee

Selanjutnya adalah pelatihan mengenai pembuatan label produk menggunakan canva serta pelatihan penerapan strategi social media marketing. Pada pelatihan ini materi yang disampaikan untuk memberikan pengetahuan peserta mengenai pembuatan label dengan menggunakan media canva yang simple serta memanfaatkan media sosial untuk digunakan sebagai tempat promosi sehingga produk dapat lebih dikenal di masyarakat.

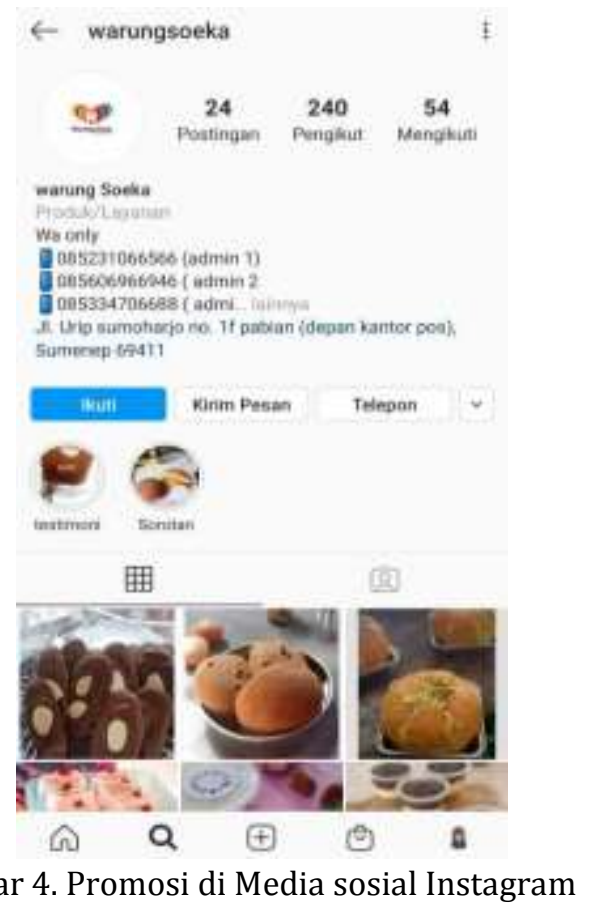

Dari hasil Analisa dan wawancara kegiatan Program KKN UNEJ Back To Village 2020 yang telah dilakukan pada mitra KKN, didapatkan hasil penjualan produk yang mengalami peningkatan. Dengan menerapkan digital marketing pada penjualan produk kue kering dan roti dari mitra dapat menekan biaya promosi serta pelanggan dapat berkomunikasi langsung dengan penjual tanpa ke toko. Hasil peningkatan data penjualan warung soeka selama kegiatan KKN dapat dilihat pada tabel berikut: 
Tabel 1. Hasil Peningkatan Omzet Penjualan Produk Terlaris

\begin{tabular}{ccc}
\hline Produk & $\begin{array}{c}\text { Omzet Penjualan } \\
\text { Sebelum 5 minggu } \\
\text { Kegiatan KKN }\end{array}$ & $\begin{array}{c}\text { Omzet Penjualan } \\
\text { Setelah 5 minggu } \\
\text { Kegiatan KKN }\end{array}$ \\
\hline Roti Boy & $15,250,000$ & $17,500,000$ \\
Bomboloni & $5,450,000$ & $7,000,000$ \\
Roti Sisir & $4,050,000$ & $5,250,000$ \\
Pie Susu & $3,080,000$ & $3,850,000$ \\
Total & $27,830,000$ & $33,600,000$ \\
\hline
\end{tabular}

Data diatas dapat dilihat dalam nilai persentase kenaikan omzet penjualan produk paling paling laris pada gambar berikut :

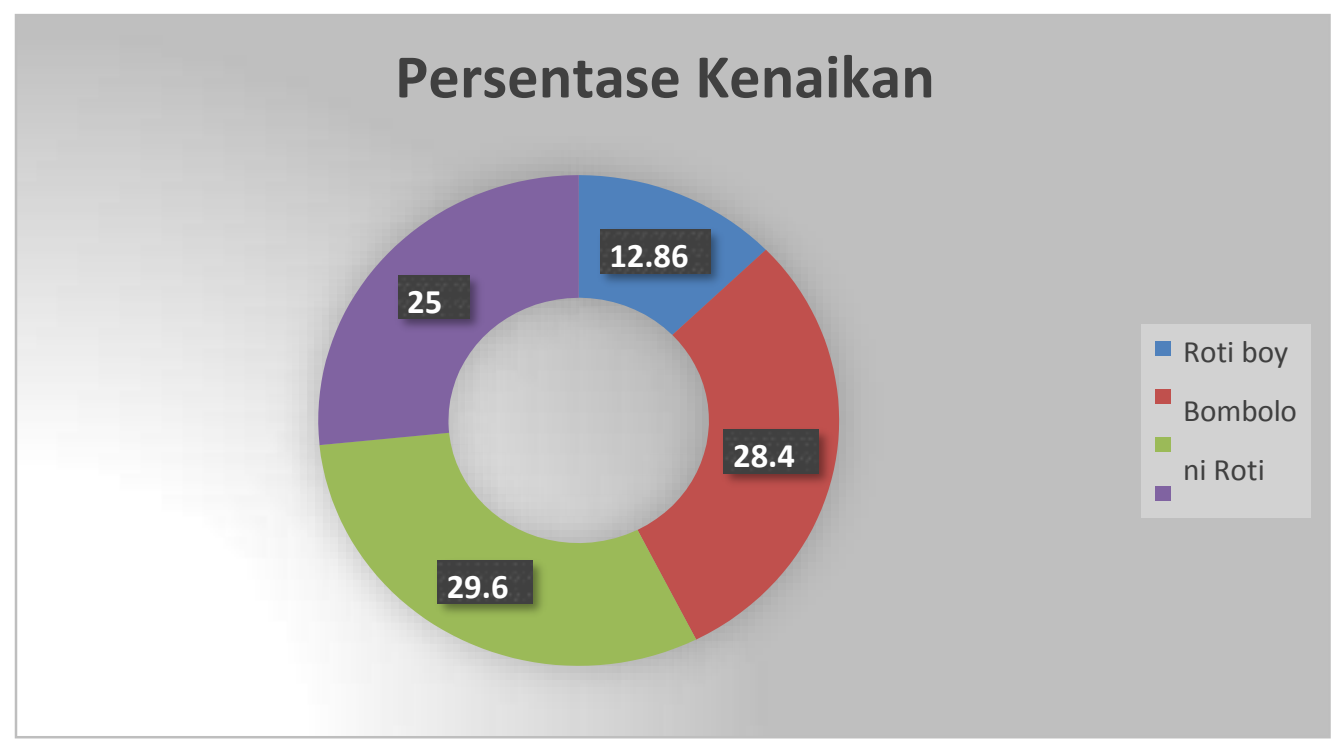

Gambar 5. Persentase Kenaikan Omzet Penjualan produk terlaris

\section{KESIMPULAN}

Dari uraian Kegiatan KKN UNEJ Back to Village yang dilakukan selama 45 hari dari tanggal 1 Juli hingga 14 Agustus 2020 dapat diambil Kesimpulan sebagai berikut:

1. Pelatihan serta praktek langsung digital marketing memberikan dampak positif yang mana produk dapat lebih dikenal di masyarakat sehingga dapat meningkatkan penjualan.

2. Meningkatkan minat berwirausaha di masyarakat desa sekitar sehingga dapat memicu usaha-usaha home industry baru yang lebih inovatif dan dapat membantu perekonomian masyarakat.

3. Hasil dari Implementasi digital marketing baik berupa social media marketing dapat bermanfaat juga untuk jangka panjang. 


\section{UCAPAN TERIMA KASIH}

Penulis mengucapkan terima kasih kepada LP2M Universitas Jember, Perangkat Desa Pabian Kecamatan Kota Sumenep, Mitra KKN, Dosen Pembimbing Lapangan serta segala pihak terkait yang telah memberi dukungan terhadap program ini sehingga dapat berjalan dengan baik.

\section{DAFTAR PUSTAKA}

Ananta Kusuma Y. P., Oktavima W., Magdalena P. N. (2020). Pendampingan dan Penerapan Teknologi Untuk Peningkatan Produktivitas Usaha Mikro Gula Semut. DINAMISIA: Jurnal Pengabdian Kepada Masyarakat, 275-284.

Garaika. Fauzi. Muslihudin, M. (2020). Pengenalan Mobile Commerce Pada Anggota Koperasi Gentiaras Untuk Meningkatkan Penghasilan Rumah Tangga. DINAMISIA: Jurnal Pengabdian Kepada Masyarakat, 300-305.

Irmawati, D. (2011). Pemanfaatan E-commerce Dalam Dunia Bisnis. Jurnal Ilmiah Orasi Bisnis. Mileva. L, Fauzi. A. (2018). Pengaruh Social Media marketing Terhadap Keputusan Pembelian. Jurnal Administrasi Bisnis, 190-199.

Martinus M., Stephanie P. A., Andreas H. T. N. (2020). Pembangunan Sistem Informasi Penjualan Pada Usaha Mikro, Kecil, Dan Menengah (Studi Kasus : Pahala Fotokopi dan Digital Printing). Dinamisia: Jurnal Pengabdian Kepada Masyarakat, 95-105.

Pemerintah Desa Pabian. (2020, Agustus 7). Grafik Statistik Desa. Retrieved from Desa Pabian kecamatan Kota Kabupaten humenep: pabian.sumenepkab.go.id/web/c_statistik_pekerjaan

Renny S. D., Oki A. C. D., Rizky N. (2019). Perancangan dan Implementasi Sistem E-commerce pada UMKM Batik di Kabupaten Jombang. Dinamisia - Jurnal Pengabdian Kepada Masyarakat, 3643.

Saragih, R. (2017). Membangun Usaha Kreatif, Inovatif dan Bermanfaat melalui Penerapan Kewirausahaan Sosial. Jurnal Kewirausahaan, 26-34.

Siska C. N., Kintoko, Puji H. P. (2020). Inovasi Kemasan dan Perluasan Pemasaran Usaha Rempeyek di Yogyakarta. Dinamisia: Jurnal Pengabdian Kepada Masyarakat, 6-11.

Susetyarsi, T. (2012). Kemasan Produk Ditinjau DAri Bahan Kemasan,Bentuk Kemasan dan Pelabelan Pada Kemasan dan Pengaruhnya Terhadap Keputusan Pembelian pada Produk Minuman Mizone di Kota Semarang. Jurnal STIE Semarang.

Syukrianti Mukhtar, M. N. (2015). Peranan Packaging Dalam Meningkatkan Hasil Produksi Terhadap Konsumen. Jurnal sosial Humaniora. 